\title{
Retrospective Reading of Fieldnotes. Living on Gypsy Camps
}

\section{Judith Okely}

\begin{abstract}
:
Decades after embarking on research among Gypsies, I examine that earlier context when there was little published discussion of participant observation practice. Snatched advice and rare texts suggested an open-ended approach rather than limited hypothesis. The anthropologist's first weeks of chronological narrative without selection of relevance, vindicate a holistic perspective. Details reveal themes prophetically to emerge as central. There are glimpses of individuals who were to play continuing or passing, dramatic roles in the years to come. Fieldnotes both reveal and conceal. Entwined with experience and analysis, they are later transformed as texts. Fieldwork reveals embedded systems inaccessible through the quantifiable. The 'merely anecdotal', so maligned by positivism, has the grounded potential, as explored here, for theoretical and ethnographic overviews, beyond place and time, in this case, residence on one Gypsy encampment during the first few weeks.
\end{abstract}

J udith Okely is emeritus Professor of Social Anthropology, Hull University and Deputy Director of the International Gender Studies Centre, Queen Elizabeth House, Oxford University. Her research includes: UK Gypsies, Normandy rural residents, Simone de Beauvoir's feminism and fieldwork practice. Her work has been translated into ten languages.

E-Mail: j.m.okely@hull.ac.uk

Unangemeldet|85.178.18.244

Heruntergeladen am |25.10.1310:11

Keywords: fieldwork; participant observation; traveller camp; qualitative versus quantitative research methods; anecdotal writing

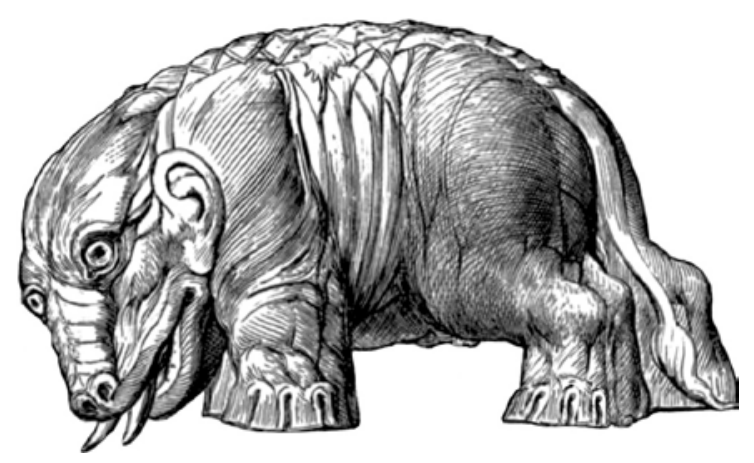




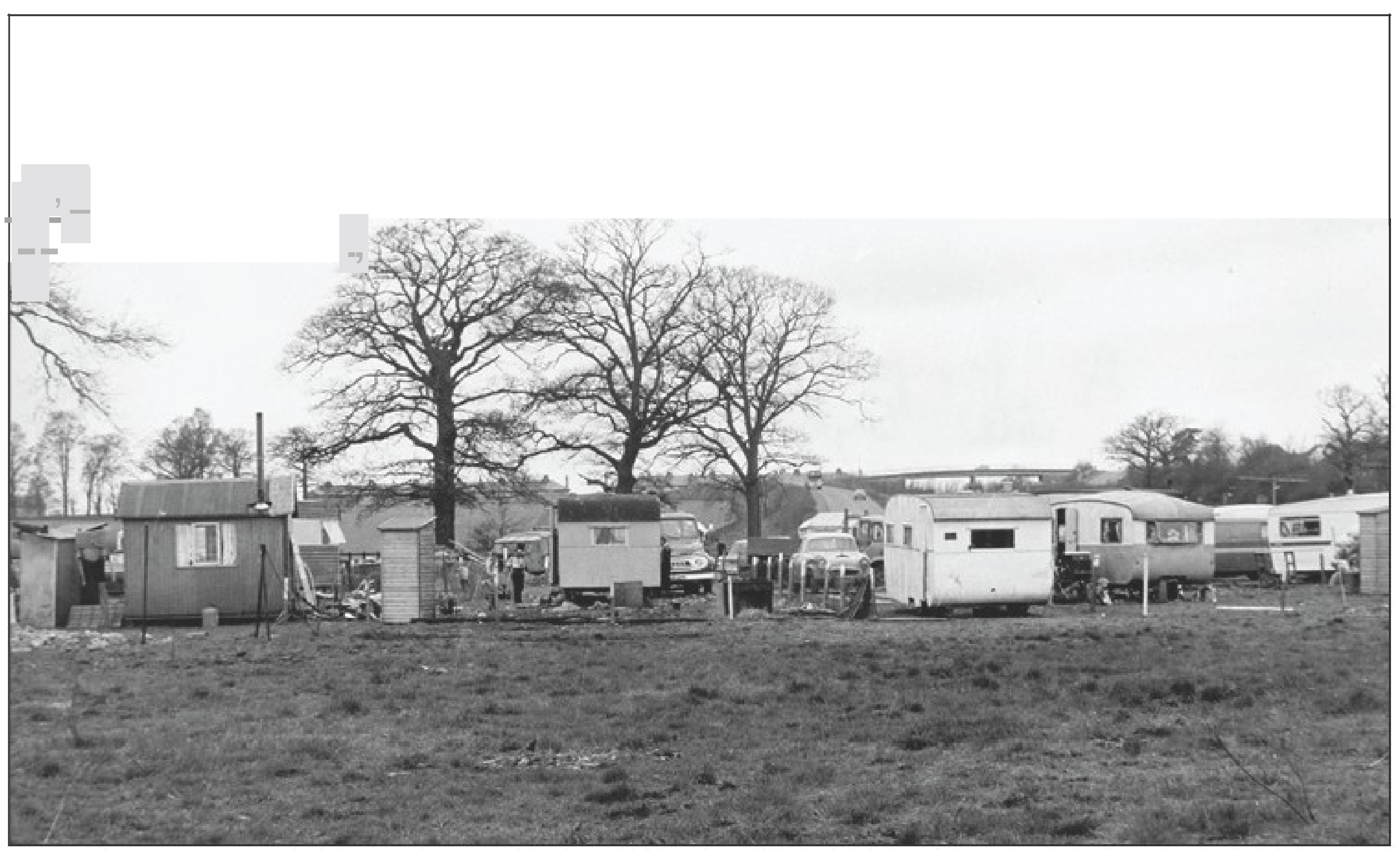

[Abb. 1] Erghtoh Travelker Camp in the 1900s [Phetr: J. Okehy) 
When I was first employed on a research project, labelled policy orientated, in the early 1970s concerned with Gypsies in England, there were no published articles on anthropological fieldwork strategies, let alone fieldnotes. This I have since documented in numerous publications and lectures (Okely 1987, 1994, 2008). Fortunately, I had learned before my Cambridgeanthropology 'conversion' course, that intensive participant observation and shared residence brought vital insights way beyond survey methods. I had accompanied my then partner Hugh Brody in fieldwork in the West of Ireland (Okely 2009). As classified 'English' we saw the diversionary strategies used by the rural Irish when confronted by outsiders. My partner wrote rough notes. I did not.

I was disappointed that I could not point to any literature to convince my sceptical employer, a civil servant seconded from the Ministry of Housing, who had recruited me from the many applicants for the research job, partly because it was believed that an anthropologist would be relevant for an 'exotic' group. She had always used quantitative, survey methods in her Ministry. She believed that only tables with numbers ever convinced policy makers (Okely 1987). She was driven by a well-meaning policy commitment to policy. She had been responsible for the first official survey of Gypsies or Travellers in England and Wales, which resulted in a Ministry Report (MHLG 1967) and eventually in legislation. This was the 1969 Caravans Act. It was so controversial that neither the Labour government nor the Opposition wanted to be associated with it. A Liberal Member of Parliament, now Lord Avebury proposed it as a private members bill. The Act made it a duty for specific local authorities to provide sites. But Barbara Adams my future boss had rightly feared that the Gypsies' perspective was not fully incorporated, for example once an authority had provided a site they gained extraordinary 'control powers' to evict all other Gypsies from their area. The police were provided with powers of arrest way beyond any countenanced for house dwelling citizens, hence her wish for research capturing the Gypsies' perspectives. She remained committed to quantitative research as the only method with political influence. The methodological implications of recruiting an anthropologist were not predicted. Thus even my first fieldnotes, which I re-read for this presentation, reflected a triumph in ethnographic methods and the privileging of participant observation over survey questionnaires and quantification. Years later, there is a brilliant set of edited collections on fieldnotes (Sanjek 1990; Emerson/ Fretz/ Shaw 1995), and collected advice on fieldwork and single authored texts such as that by Aull Davies (1999). 


\section{Positionality}

Before my fortunate appointment at the Centre for Environmental Studies, London, I had studied with Edmund Leach on a one year Cambridge postgraduate conversion course after a degree in Politics, Philosophy and Economics. As part of our postgraduate degree, Leach convened a weekly two-hourseminar with just five of us. For theentireacademicyear wewent through all of Malinowski's work, except his Diary (1967). Leach said it should never have been published. Some time after my fieldwork, I published an article in which I argued that Malinowski's diary was informative for the contradictions in fieldwork. The anthropologist should confront his/ her subjectivity and its interrelation with the field (Okely 1975a, 1996, Ch. 2).

Onepuzzle, which inspired mewas the fact that my ex partner, Hugh Brody had written up theIrish fieldwork in the first person, as imagined lone hero. Reviews had praised his apparently innovative autobiographical style. In fact, he had been accompanied by J udith' his honorary 'wife', wearing a Belfast Woolworths 'gold' wedding ring. This left me sceptical as to how authors re-construct fieldwork in texts. The accompanying partner may be erased or thanked as anonymised 'wife' in the preface (McDonald 1978; Okely 2009). Puzzles can be transformed into something creative. Hence my edited Anthropology and Autobiography (Okely/Callaway 1992) where I argued it was important to explore the consequences of the gender, age and ethnicity of the anthropologist in the context of the field.

\section{Participant Observation}

First my struggle to argue the importance of long term, intensiveanthropological fieldwork among the Gypsies instead of my director's plans for a nation wide 20 page questionnaire to be delivered ideally to 500 families, then computer analysed. I found little textual guidance. The Appendix of the sociologist Whyte's Street Corner Society (1943) was one of the few texts outlining ethnographic fieldwork. I then discovered the anthropologist Hannerz' appendix for Soulside (1969). Both Whyte and Hannerz had done fieldwork among a stigmatised urban minority in the West. Before studying anthropology, I had already been inspired by a sociological study Education and the Working Class by J ackson and Marsden (1962). The strength of their supposedly 'objective' sociological study was 
also subjectively driven. They had conducted interviews on the schooldays of adults with working class origins. Both explicitly and unknowingly, the two authors drew on their similar biographies.

Theirs was in fact partly a retrospective ethnography (Marcus/ Okely 2007).

I eventually won the struggle to live on Gypsy camps when, thanks to a very liberal local official, I was given the use of a caravan, first as de facto warden, then as self described 'student' without official duties. I had wisely delegated the dreaded questionnaire of some 20 pages, devised by my Director to Penny, a social worker, to administer. She observed how the Gypsies faked or dodged answers to the absurdly intrusive questions. Penny knew many of their alternative conflicting facts. Some said they had never been married before. Penny knew otherwise. They claimed never to have travelled perhaps because they thought this was what the questioner wanted to hear. This inconsistency between what people say they do and what they actually do, was exposed by Deutscher (1970). My director, recognised the inconsistency in the questionnaire 'data', declared they could not be 'coded'. Thus I escaped spoiling my fragile rapport with the Gypsies. I would have been identified as official interrogator. Indeed, in my early field notes, I recorded the change in rapport between a Gypsy woman and Penny, after the survey. I recorded a new coolness in contrast to openness before.

Before moving onto the site and for a preliminary week staying in rented lodgings up the road making day visits, I had recorded my observations, but as a formalised report on set themes. I had classified in advance presumed relevant issues to isolate.

\section{Advance selection of Relevance}

Re-examining this report, I realise how fortunate I was to have abandoned that approach. In pre-identifying relevance and themes, I was inadvertently ignoring or excluding others at the outset. I was imposing premeditated topics in the first days of ever having met Gypsies. This obsession with advanced themes is embedded in a positivist social science legacy. I am still confronted by this scientism in other disciplines. A few years ago, I watched an Oxford professor of Economic Development confronting an anthropology doctoral student embarking on fieldwork among the Bedouin. In the Development seminar, the student was harangued because she did not have an hypothesis: 'If you don't have one', the economist insisted, 'You will only drift'. This student had already established long-term contact with the Bedouin and had the fundamentals 
of the language. I intervened, arguing that this is what anthropologists do, when they fi hit the field. They should be open to what is there. This could indeed be a form of drifting. Malinowski declared:

Good training in theory, [...] is not identical with being burdened with 'preconceived ideas' (...). Preconceived ideas are pernicious in any scientific work, but foreshadowed problems are the main endowment of a scientific thinker. (1922, 9) (my emphasis).

Powdermaker, a student of Malinowski, insisted:

A lack of theory, or of imagination, an over commitment to a particular hypothesis, or a rigidity in personality may prevent a field worker from learning as he stumbles. $(1967,11)$.

My search for fieldwork guidance in teaching methods courses has resulted in a forthcoming book Anthropological Practice (Okely 2011), I have interviewed over 20 anthropologists on their fieldwork around the world. All switched focus in one way or other once in the field.

In this article I emphasise the importance of being open to what is before you when approaching fieldwork. You enter with all past reading, past knowledge and indeed life experience. Agar's brilliant The Professional Stranger (1980) emerged a decade after my first fieldwork. He confirmed so many of the ideas I had grappled with in relative isolation:

When you attempt to describe some aspects of a group's life, you may be drawing from conversations, casual observations, twenty formal interviews, a previous ethnography, two novels, your general idea of the human condition, childhood experiences with your parents and who knows what else. (Agar 1980, 6)

Nothing is irrelevant. It depends what you bring with you. But you have be disponible, to use Breton's wonderful term (1937). I had been fascinated by surrealism when I studied at the Sorbonne. Before 1970, I had never knowingly met a Gypsy, although I had been acquainted with poems, stories and Bizet's Carmen. The ubiquitous representations of Gypsies in public discourse are also crucial (Okely 2008, 60-64). 


\section{Field notes as Emergent Narrative}

Given theabsence of any so-called methods training, I eventually wrote detailed field notes, thanks to the advice of Malcolm McLeod. He had done fieldwork in Ghana, supervised by Evans-Pritchard. In desperation, I contacted him when faced with my director's insistence on questionnaires. He said I should write down everything I had seen, heard or smelt, without editing, all in a stream of events in diary form. Ideally, he said with a mischievous grin, I should fill an entire exercise book every day. In my first weeks, I had unwittingly omitted the stream of events. Seemingly unimportant details were not recognised as potentially significant. I would subsequently acknowledge Malinowski's emphasis on 'the imponderabilia of the everyday' (1922).

Over the years I have more explicitly recognised that anthropologists cannot predict in advance the key themes, let alone main topic which will emerge over time once in the field. Thus when I finally gained privileged access to Gypsy camps, I had no idea that I would be pondering the Gypsies' animal classification, their liking for hedgehogs and suspicion of cats. My director would have been bewildered by my concern with seemingly folklorist trivia. Indeed, when I asked to read The Gypsy Lore Society J ournal found only in a local London library, she, the civil servant, said I was to use my limited days of annual leave for this. Ironically, since my fieldwork stretched to seven days a week, I had accumulated considerable 'time off'.

Revisiting my notes for this paper I had to sort through box files in my attic. I could not have imagined they would be the starting point for books, multiple articles and resonances far beyond the Gypsies in Southern England to the study of Roma and Gypsies beyond even Western Europe. All that is vindication for in-depth anthropological fieldwork in limited locations and over a concentrated time span.

Here I fall back on my mentor Edmund Leach's brilliant article An anthropologist's refl on a sociological survey (1967). I was not aware of this even when publishing The Traveller-Gypsies (1983), but referred to it in 1987. Leach, in a critique of a survey-based study, argues that one in-depth micro study can best explain a mass of quantitative data (1967). Long-term participant experience helps to make sense of even the most detached survey. Confronted with an extensive survey of landownership in 57 villages in Ceylon (Sarkar/Tambiah 1957), Leach drew on his fieldwork in just one village (1968) to counter the misleading quantitative interpretations. He pointed to the system, which may explain the 
numerical andindeed contradictin crucial ways. Thesurveybased studyooncluded that ahigh proportion of villagers werelandless peasants. Leach pointed out that many would inherit theland from their elders.

Similarly, my fieldwork was based in one limited county producing the grounded material. My residence on camps took place from 1970 to 1973 with return visits up to 1975. Intensive anthropological fieldwork raises questions beyond specific localities to the study of others across the globe.

Yet imagine my bewilderment when in the 1980s, in the prestigious department of sociology, at Essex University, as lone anthropologist when such research was denigrated. My sociology colleagues repeated endlessly that so called qualitative research was merely 'valid' i.e. only accurate in the micro location, but not 'reliable', because not generalisable. This fits with the increasingly hackneyed put-down of evidence that is 'merely anecdotal'. It suggests that such material is potentially misleading because not repeated and tested by quantitative criteria. But I was to find that an entire worldview or a system may lie in a single anecdote which reveals an entire structure. The new trendy 'evidence based' label for research depends on the quantitative, but implies that none of our research is evidence based, i.e. we invented it.

My later article (Okely 1994) explored my Eureka moment when reading a 1922 article by T. W. Thompson. A part time scholar and Anglican clergyman, with anthropology references such as Haddon, Thompson frequented Gypsies. I suspect this was in the weekdays when he was not preparing sermons. He published some solid ethnographic articles in The J ournal of the Gypsy Lore Society. In a stray footnote he recorded a Gypsy who said that they considered cats and dogs dirty because they licked themselves, whereas horses were clean because they did not. This one anecdote, as curious aside, led me to understand the classification of animals into a logical system, evidence indeed!

I had already been influenced by the work of Douglas (1966), Leach (1972) and Tambiah (1973) on animal categories. Thus social anthropology, in the study of all cultures and peoples and contexts around the globe, raises questions of comparison and contrast, beyond locality, place and indeed time. As it happens, I am delighted that other researchers on Gypsies, Travellers and Roma were challenged to consider my kinship findings, analysis of pollution taboos, arguments concerning economic strategies, travelling patterns and relations with non-Gypsies in multiple contexts across time and place. Thus my research raised questions across not just English county boundaries, but across countries in theentire European Continent and in North America. NowI discover that students 
of Bernhard Streck are studying Gypsies or Roma in South America. When through the late 1970s, I met up with Ignacy-Marek Kaminski, Will Guy and Anne Sutherland who had done fieldwork among Gypsies in Poland, Slovakia, Sweden (1980), Czechoslovakia (1975) and the USA (1975), we would exchange ethnography until we were faint with intellectual engagement. The pioneering work in North America of Rena Groper (1975) was already inspiring concerning the Gypsies' multi-occupations. Indeed work on Gypsies raises questions and comparisons concerning very different nomads across the globe, as the work of Bernhard Streck confirms.

\section{Re-Reading}

In my article on fieldwork (Okely 1994), I described the painstaking process of sub classification of emergent themes, then analysis of my entire fieldwork and notes through several years. Here I have re-examined only my notes for the first few weeks when recorded as continuous narrative.

Having convinced my director of their value, to her credit, she arranged for my hand scrawled pages to be typed up by the Centre's typists, causing considerable excitement. The typists were soon reprimanded for discussingmy 'adventures' - much moreinteresting than mathematical traffic flows or housing provision. All this was before word processors and laptops, which have broken down the division of labour. This delegation of typing to unknown others prevented me from recording any Malinowski type musings, as if a personal diary. I dared not expose inner thoughts, especially when asserting the scientific value of field notes.

Rereading the notes, I recognised that I did not systematically describethe physical appearance of individuals. Thus some passing acquaintances or seemingly less significant persons, remain names without remembered faces. Additionally I could not, indeed dared not write in front of my hosts. The context may explain this. I quickly realised it would be appear highly provocative to appear with pen and paper. For a largely non-literate group, the act of writing was associated with the police or other officials. Curiously, one Gypsy described how they did not mind someone with a tape recorder noting their statements. It seemed that the act of writing remained a mystery open to distortion beyond their control. In other cultures, the act of writing was perceived as an admirable act of power. It was symbolically imitated by an Amazonian chief after seeing Levi-Strauss writing (1973). Powdermaker also found that people expected her to make notes at every funeral (1967). 
The second reason for the relative brevity of some accounts was the time factor. I could only write late at night or when away from the camp. I sometimes disappeared to the local library. Later I used a friend's spare room in a house 15 minutes drive away. I explained I was visiting a friend.

After re-examining those early notes, I recognise how specific events have 'improved' through the telling. Over the years, I have been continuously assailed by non-anthropologists as to how I could have lived with, indeed survived being with the Gypsies. Again and again, despite attempts to divert the familiar or sometimes bizarre questions, I have been called upon to narrate or entertain my non-Gypsy listeners. I have kept to the facts in undergraduate lectures, but have been tempted to emphasise the dramatic twists and punch lines on many social occasions. Anthropologists have not only distant readers but also listening audiences. As lecturer/ performers, we witness the audience response. Thus the narratives have, I acknowledge, been embroidered for dramatic effect, but never fictionalised. Perhaps what seemed normal to me was received as melodrama. I had not at first predicted how much the fact that I was living with the Gypsies would evoke such curiosity or indeed people's compulsion to tell me about Gypsies. Most of this was imagined representation (Okely 2008). I have explored in that 2008 article 'Knowing without Notes', how I also drew on these and other aspects, which I had not written down.

A significant number of the 20 anthropologists I interviewed for my book Anthropological Practice (Bergin press), revealed that when writingup their doctorates and for early articles, they did notre-consult their fieldnotes. They drew on their memory. Seemingly, the act of writing down had engraved the details and preliminary ideas as a mnemonic device. Entwined with unscripted experience and analysis, fieldnotes are transformed as texts when anthropologists write up. At the extreme end, I learned that some anthropologists wrote few notes. My supervisor, Godfrey Lienhardt, was astonished to read my first jottings as narrative. He joked how his scribbles had been blotted out by liquid libations when with the Dinka. At one point he exclaimed: They are moreviolent than the Dinka!' His brother Peter had to retreat to vomit after reading something about the toilet conditions on my camp. Ignorant of the full extent of my notes, Godfrey advised that, for my doctoral viva, I bring them as back-up. I explained that my typed sheets filled many boxes. My topic sub-filing, not counting notes on relevant reading of 'the literature' filled at least three multi drawer filing cabinets, requiring a special delivery van. He got the point.

In contrast to Lienhardt, the photographs of Malinowski and the discussions by Clifford and Marcus (1986) and Sanjek (1990) demonstrate how central is the act of writing in the field. They 
need not do it in private. I return to the visible written record which historians so value as archive. Now with the wealth of literature on writing in the field, there is an excellent exercise, which I can subsequently apply - namely thinking through the act of writing up what has first been recorded as fieldnotes. Van Maanen (1988) suggests writing up in different styles. His classifications are:

1) Realist
2) Impressionist
3) Confessional.

The latter is best defined as subjective with at least the use of ' $\mathrm{I}$ ' in the text. Although I do not fully agree with the rigid typology, retrospectively I see some varied styles depending sometimes on the readership or the writer's inclinations. The fieldnotes are so-called evidence, but the anthropologist draws on her entire experience. Elsewhere, I have indeed explored how fieldwork is an embodied experience, not simply a cerebral one. Such material emerged best when I asked the 20 anthropologists to recall and describe their embodied knowledge, albeit in disembodied words (Okely 2007).

As an example of specific styles appropriate to context I use my eventual publication concerning Gypsy law and alternative resolution of conflict, which included the account of a feud, resulting in a murder. I had written it up for my doctorate for the record but managed to gain a 30 year embargo on public access. In 2004/ 5 I dared to revisit the chapter and update it for publication in a sociology journal where I hoped the mass media and indeed rival non-anthropologists, such as some linguists, who dislike my work, would not read it for public internet scandal mongering. My deliberately dramatic opening was there to engage the reader. In effect it engaged with the arrival of the anthropologist. Pratt (1986) has pointed out how, despite the intention of anthropologists to write as scientists, they drew on literary tropes and especially the 'arrival'.

Here I am concerned not only with the effect of the arrival for the anthropologist but also with the effect of the arrival of the stranger on the people, her hosts. In the 2005 article I commenced with the incident of a handsome Gypsy entering my trailer ostensibly for a chat the very first night on the site:

During the week I moved into my trailer caravan on a temporary Gypsy/ Traveller site, I experienced two incidents which either immediately or much later, reflected the use of the stranger. In this case, I was a non-Gypsy or gorgio woman and associated with the dominant society's persecution of the semi-nomadic ethnic group. (Okely 2005, 691). 


\section{1st week of visit}

Katie knocked at my door. I read stories. At first she showed little interest in the fuzzy felts. Couldn't concentrate. But later she asked for them. Very neat in putting all the pieces back. Has a strong accent_ her gentle appearance is already belied by a certain boldness. N.B. She was extremely quiet when she first met me. 'Amie' also came round a little later. Said her brother (8) didn't know I was here because he had gone with his father and uncle to visit. i.e. he had gone to be away from the women. 'Boys don't like girls'. (Was this a description of the scene at her mother's where I later saw two female visitors?). She also said 'darts is for boys'.

She asked about my fur hat-whether it was a pussy cat. I said 'a bonnet'. She 'A cat bonnet?'. Both Katie and Amis have each a kitten called 'Blackie'.

Amie kept talking in a baby voice, 'Miss' 'Miss\. Became quite grumpy and niggly if I didn't read a story. N.B. Neither could concentrate till the end of the page. Pictures were vital. They kept wanting to turn the page to see a new picture. Amie's mother Mary called out through the site. I took Amie (very reluctant) back. Her mother greeted me and I had to cut the interview short by explaining that Katie was alone. Later (soon after) Katie's father called across the site. ( N.B., Once before her mother had actually come to collect her.)

I took the little girl as far as the plot. (Should have been bolder and knocked on their hut door. They were in the hut-6p.m. The trailer lights were not on.

Mary 'They always call you Miss because they think you're a teacher'.

9p.m. Leo knocked-didn't wait-burst in saying 'Nigel' (the warden). When I told him Nigel was away abroad, he half confessed that he had been told this. Stood by the fire near me. I moved across the trailer. He said 'don't bother about giving up your chair; Sat on the arm, while I sat on the bed,

L. 'People will be talking'

Jo. 'Yes I shall be talking a lot to the women. I don't want to upset anyone'

L. 'I told Mary I was going to Richard. If she knew I was here (gives gesture if someone clamping down). Said he would go to Richard afterwards. Asked me if I had enjoyed my holiday. I said yes but wasn't sure whether he meant my last stay here or my spell in London after. I felt considerably uneasy, couldn't encourage him to stay in case his visit were to be misinterpreted.

L. 'I always come and see Nigel every evening' (i.e. explaining his action) 'I suppose I'd better let you get on with it, see you dear'.

Great regret at loss of friendly contact, but too dangerous to over cultivate. 
I now reveal how I transformed as follows, in the 2005 article, some of those condensed notes to an elaborated narrative:

The first evening there was a knock on my door and a handsome male Traveller came in. He was holding his young child in his arms. My first naïve reaction was 'Good. Here is someone to interview'. But his charming smiles and ambivalence signalled something else. I was in my twenties and apparently a single woman and the carrier of the stereotypes of gorgio women as sexually uncontrolled and available. (Okely 1975b)

Eventually, I asked if his wife knew he was there. When he said no, I suggested he leave. I did not then know that he had been the centre of a feud ending in death. Many months later, I was to be used as a means of censure of this man's womanizing reputation. I was able to extricate myself by turning the incident around through a playful act, as will be demonstrated below:

That same day, an older Traveller had assured me that I would be safe with the Travellers to look after me (Okely 1983, 41). Yet he was ambivalent towards me as outsider. Within the week he complained about a neighbouring family's Alsation dog and tried to convince me it had mange so I should ring up the RSPCA. In fact, the real annoyance was its repeated barking. I instinctively refused. If the dog had been confiscated, it would be convenient if I, the gorgio, had been accused of reporting the problem. No Traveller would have been accused and my residence on the camp destabilized. The Gypsy would have been rid of both the dog and the gorgio would be blamed. (Okely 2005, 691-2)

It is intriguing how limited, near perfunctory, is the detail in my notes. But I have elaborated it in dramatic near literary form as article opening. I have also mentioned a few days later, as bare facts, a woman's first husband being in jail for manslaughter - and this fact via a lawyer whom I was to befriend. My notes record that he did not deliver the fatal blow but that the all sides of the feuding Gypsies had agreed whom should be found guilty in court.

Over the years, the thinking and oral recounting to friends or students has assisted a poetic. The central parts of my 2005 article are more 'realist' in Van Maanen's terms, in that I describe dispassionately the handling of disputes, some means of which are violent. I modify the drama by citing cross-cultural similarities from the anthropological literature from around the globe, especially the detailed articles from Africa. Here the writer is detached and writing with academic and generalised 
and theorised authority. Then as the article ends, the text reverts as a finale to the specific Gypsy feud and murder.

I return to the same man who entered my trailer that first night. There is a final twist and an account of my intervening in mock acting, which I repeat below. The joke worked by defusing the absurd rumour (Okely 2005, 708). I had combined the confessional as personal, the impressionist and detached realism all in the one article. The only major omission in the published text is the very brutal manner of killing. This was because I was writing up this material, long sequestered in my doctorate, now for the public domain. But the months of writing for publication were those when the leader of the Conservative party as prelude for the 2005 election had placed full page adverts against Gypsies in several newspapers.

The 2005 Conservative party electoral campaign included the full-page advertisement, signed by Michael Howard, the leader of the Conservative party a highly provocative declaration against the Travellers' use of their own land for camping sites without planning permission (The Independent on Sunday, 20 ${ }^{\text {th }}$ March 2005). Sedentarised societies always stigmatise nomads. The impact of this advert was terrifying. [1]

The problems of Gypsies lacking private or council sites had already grown by the 1997 Labour Election victory. Legislation reinstating sites might have pre-empted the growing accommodation crisis and attacks on Gypsies. With such a witch hunt and public hysteria, I feared the tabloids might actually read an academic journal and recount as headlines how the victim had been smothered in petrol along with other camp invaders. Then the mother of the legally accused had been the one who threw the match, which caused eventual fatal injuries.

In 2002 I had indeed been invited by a former student, convening an anthropology course, to teach in Hull prison. When I commenced with the details of the feud, I had never had such an attentive class-twenty male prisoners leaning forward with maximum attention. As I worked towards the finale, I asked them how they thought it was resolved. The reply from several of my hitherto silent students was: 'They stitched him up'. They predicted rightly. Thus each detail of ethnographic fieldwork may be transformed, omitted, elaborated or ignored. Such minutiae may have been first recorded in field notes but they may merely linger in the anthropologist's memory awaiting analysis or narrative. Time may improve the telling or delete.

In the concluding pages of the 2005 article I explored:
[1] This Conservative media campaign was partly triggered by the Report from the Office of the Deputy Prime Minister (2004). In the latter there appears to be an informed attempt to address the Traveller-Gypsies' need for further encampments, including one, which they own and run themselves. However, this came at the end of the Labour government's second term. 


\section{The anthropologist as displaced moral target}

In the introduction I described the visit to my trailer by someone. This was Leo from the case study above, and whom I at first naively saw as research informant. Fortunately, my instincts were right and I soon sent him away. Thereafter, I befriended his wife and, wherever possible, only talked to men in the company of women (Okely 1975b).

A year into my fieldwork, I returned from a weekend visiting my partner in Cambridge and casually informed Pauline, a gorgio (see above), that I had a stomach upset triggered by a copious college banquet. Vulnerable to moral stricture, she told everyone that I was pregnant. She had learned to divert conflict away from herself. The story blossomed. Frankie, another camp resident, joked that I was pregnant by Leo. It was a way of censuring him for having 'run off with' Bill's wife and being the trigger for the murder. Every day I would be told that yet another family or nearby camp had been informed; even the local garage. Frankie appeared at my door with some of Leo's clothes because, he said, Leo would be moving into my trailer. By then I was panicking. Leo's wife was no longer smiling. Would this be another combat, but with the outsider gorgio as physical target?

I resolved it as follows. In my trailer were a number of dolls given by a local charity for the 'poor Gypsy children'. I wrapped one in swaddling clothes and strode over to Leo's trailer when I saw that it was crowded. 'No one' I said 'came to help me. I have just given birth to this baby all on my own. Now I demand financial support from Leo the father'. My performance was greeted with shrieks of mirth. Leo's son snatched the doll, this imaginary rival, and smashed it against the trailer wall. As predicted, the story was relayed around the region. For weeks, the Travellers congratulated me for 'mucking in' and being able to 'take a joke'.

It might have been a different story if the anthropologist had obeyed the positivist rules about remaining the distant social science observer (Okely 1992). The anthropologist, once stranger but always outsider, works within and between as witness, collaborator, ally or even dupe. She is a ready object for settling old scores and internal disputes. (Okely 2005, 707- 708).

This is one example of how fieldnotes are transformed as published text. It demonstrates how even in the first few weeks the anthropologist may unwittingly be confronted by key aspects of the subsequent ethnography and potential monograph. I note below in my chronological field notes 
some of the emergent essential themes. Each could point to core aspects. These so-called anecdotes so arrogantly dismissed by the positivist quantifiers are crucial.

Positionality of the researcher as young, unmarried woman in at first rather hippy clothes: Younger mens' sexual innuendo.

M. told me to holler as I was alone at night. The quote has been expanded and became an icon for some. (Okely 1983, 41)

Overtures from Tony re 'marriage' living with someone I was later to defend as his character witness in the Old Bailey, the highest court of the land.

I was seen as literate for help in reading official letters.

First encounter with Mrs F with three girls and two year old boy chatting me up to put in a good word to get a cottage to buy. A few years later I was to visit them regularly in their newly acquired bungalow when the man asked me to teach him literacy skills.

Gender identification across ethnicity: Gypsy woman's confessional of miscarriage and births to the Gorgio outsider.

The same woman confides (to stranger therapist) about her child who had been killed by a gorgio reversing his car on the site. This intimacy to the stranger anthropologist was to consolidate one of the most important associations throughout the entire fieldwork.

She also confided vivid details of giving birth and her start of labour 'If only there was a woman I could have talked to'. Again this would alert the anthropologist to views of childbirth to be explored in a key article. (Okely 1975b)

The anthropologist was entrusted in these early weeks to child mind for this woman. But this was seen as neglect by other Gypsies. Again the maternal role and suspicions of gorgio outsiders were exposed. 


\section{Gender external stereotypes}

[2] Cf. K. Thomas, the historian of wider British witchcraft.

\section{Gender and sexuality}

The Gypsy woman recounted how a gorgio farmer kept making passes at her - You women are more lively'. All proved pointers for the article on Gypsy women (1975b).

The stranger as therapist/ outsider confidante

The personal and private disclosures of ethnic difference. This woman had been brought up in a house and was articulate on the contrasts.

Fortune-Telling: the anthropologist is given an extended case study with its procedures - something never to be repeated through the years - the basis for my article (Okely 1996, ch. 5).

The detail on fortune-telling methods proved prophetic concerning the acquisition of people's possessions two years later when I was persuaded to exchange my gold earrings for something of far lesser value. I had forgotten the procedures! I did indeed write up this anger in a private diary, which I had begun to use, much later into fieldwork.

Detail of curse made by an older Gypsy woman as witch. [2]

\section{Travel and work patterns revealed}

Travel and persecution involving relations with officials and police.

Preference for travelling 'a fortnight here and there'.

Fruit picking: strawberry/ potatoes shown as part of an annual routine.

Work: tarmaccing, farm work, scrap dealing, selling at doors, fortune-telling. 
Comments about farm work especially that it did not bring much money. Decades later this work would be done by East and Central European migrants, including Roma.

\section{Gorgio work contacts}

'Leo' always went to the same man to deliver scrap and gave the gorgio a whisky present for loyalty. [3]

\section{Sedentarisation and Diaspora}

One family's expressed wish to purchase land for bungalow (succeeded four years later).

Details were revealed of kin in houses in SE England and revelations of kin in Canada and the USA. Subsequently I would learn of kin in Australia but lost contact. No fixed address even for postage. (Today, theinternet and mobile phone have enhanced communication).

\section{Kinship/economy}

Kinship loyalties. I was extra alert to this drawing on my classes with and reading of Meyer Fortes as well as Malinowski only a few months previously.

I noted that gorgio outsiders could not get the jobs (Kin was a basic economic group). One gorgio in the neighbourhood declare: 'They stick together'. Gorgios were contracted in first, to type estimates, if with literate skills, secondly, if young and male, to do heavy manual work. These 'tramps' were recruited for the day and then dropped off, maybe to sleep rough.

\section{Marriagerules/sexuality}

Insights into marriage, fidelity and remarriage.

Marriage/ partnership rules apply, once a couple have spent the night together. Marriage was not necessarily confirmed by gorgio law.
[3] Expanded in Okely 1996, 'Trading Stereotypes' Ch. 3. 


\section{Ethnic performance}

Performing as Gypsy to outsiders. [4]

My queries of their motives.

Insights into schooling: professed desires or sceptical resistance.

Confiding to me about one Gypsy woman hiding kids from school while at first saying she wanted them to attend. 'She thinks she can get on a site if she tells you she wants her kids to go to school' (again confiding about perceived performance for outside officials). I later argued that children may be educated but not schooled (Okely 1997a).

Hopes/ demands for water provision/ good reference in planning access.

Police [...] Leading me into defence of the police until I showed alternative critique.

A policeman had fractured a Gypsy's shoulder [...] police brutality (see Okely 2005).

Initial denial of identity, then acknowledged as Gypsy.

Stories about not being recognised as Gypsies i.e. seeds of performing identity (Okely 1996, Ch. 3).

\section{Reciprocal exchange}

I compare experience about police searching vans e.g. my boyfriend's.

\section{Childrens' alternative education and socialisation [5]}

Children's fear of strangers outside the camp.

Inventiveness among children e.g. repartee and rabbit skinning and selling.
[4] See later developments in Okely 1996, Ch. 3.

[5] All this section developed in Okely 1997a. 
Child taught how to appeal to outsiders on the doorstep.

The use of children to persuade the sceptical but potential gorgio customer.

Teaching children to appear vulnerable and pleading, to gain goods.

The Gypsy woman confidante tells me how she brings them up a split life.

\section{Intergroup conflict resolution by threats and evasion}

No challenge of rivals on a stopping place as it was illegal for them also to be at a specific place.

Violence between rivals.

Site size “It isn’t the number, its who you put on it’. [6]

Use of outsider to resolve Gypsy intergroup conflict (Okely 2005).

Mention of dog with mange asking me to contact charity (Okely 2005).

Dealing with theft of vehicle after my lights were out.

Note Taking: Attitude to journalists, note-takers all conflated as hostile and dangerous (As already revealed above)

'I can always smell them out' (police) motioned to side pocket 'When they get that notebook out I always tell them to go'.

E 'One lady with tape recorder from abroad 'Other travellers from abroad would want to know, so we told her everything about what it was like to be on the road today.
[6] This points to kinship organisation fully developed in Okely 1983, Ch. 10. 
M 'She didn't write anything down. [...] She said "I don't need to, I can remember what you're saying. [...] Its them that start writing that I don't like"'.

'I may be no scholar but I know how to fend for myself.'

Charlie (an 8 year old) 'You're a reporter aren't you.' His mother never invited me into her trailer. [...] I had naively told one couple I had once written an article about living in a country cottage. Word had got round.

\section{Animal classification}

Unlucky to say rat snake or monkey must say long tail’. [7]

J okes about selling wives as horses - 'She can trot and had just one owner'. [8]

Death rituals

Seeds of death beliefs (Okely 1983, Ch. 12) e.g. fear of dead child's ghostin unburned trailer.

\section{Cleanliness}

Here I was already alert to such issues thanks to Douglas' (Purity and Danger 1966).

Quotes: 'people think we're dirty'. Of my trailer interior - 'Isn't it untidy here- you need a big box for the books'. All these are advance clues as to my concepts of 'Inside/ Outside' for bodily and spatial divisions and pollution (Okely 1983, Ch. 6).

Politics at national level

Discussion of Gypsy Council and evictions [...] leading to emphasis on decentralised political organisation.
[7] Cf. Rex Clarke's research (1970) among Shetland fishermen: When talking to Shetland fisherman about land animals and mistakenly using their names when in the boat, he had to say 'Cold Iron' when uttering the land label 'rabbit' when in a boat on the sea.

[8] See Stewart's later work on horse trading and gender (1997). 
Romany language useage. Little did I know that my observations on their limited use of Romany while resorting to significant, key words would later outrage of linguists. One said he wanted to burn my book (Okely 1997b, 240).

\section{The Key Associate}

The notes reveal and confirm the crucial role of an indigenous member as facilitating intermediary. [9] The young married woman eased my entry and knowledge. She had a Gypsy father and gorgio mother. Her hybridity was an advantage for the incoming stranger. My subsequent dialogues with anthropologists confirm this crucial aspect of fieldwork (Okely 2011). Again it was important to size the chance. As Caplan recently suggested (2010), they also choose you. It may also depend on the gender, age and personality of the researcher and associate. This woman of my age, explicitly said how she sympathised with me because she had had a similar problem when first coming as house dweller after marriage, albeit of Gypsy parentage, but now knowing her way around. She chaperoned me through awkward moments and context.

Simultaneously I was beneficial to her. Grief stricken after the accidental death of her toddler, she described how neighbours and relatives could no longer listen to her. I was supportive listener into the early hours, alone in an old van, complete with internal coal fireplace. I was the stranger therapist who listened without judgement and with minimum intervention (Okely 2010).

In return, she confided additional insights into the experience and living of Difference, for example, the act of confusing outsiders and the role of exoticism for the Gypsy as fortune-teller. Paradoxically, she herself did not fully understand fortune-telling as a form of psychotherapy. Years later my detailed notes were elaborated in Okely (1996, Ch. 5).

\section{To Conclude}

In anthropology, intensive fieldwork reveals embedded systems inaccessible through the quantifiable and distancing questionnaires. In this case, just the first few weeks of chronological field notes, recorded without advance selection of relevance, on a small Gypsy encampment of some 15 families, demonstrates the power of open-ended participant observation. The 'merely anecdotal', as explored
[9] Cf. Doc in Whyte’s Street Corner Society ([1944] 1966) 
here, so maligned by positivism and a travesty of science, has the grounded potential for long term theoretical and ethnographic overviews and explanations, beyond place and time.

\section{Bibliography}

Agar, M. (1980) The Professional Stranger: An Informal Introduction to Ethnography. London: Academic Press.

Aull Davies, C. (1999) Reflexive Ethnography: a guide to researching selves and others. London: Routledge.

Breton, A. (1937) L'Amour fou. Paris: Gallimard.

Caplan, P. (2010) The Transcendent subject: Biography as a medium for writing "lifeand times". Paper delivered to the ASA conference, Belfast.

Clarke, R. (1970) Fieldwork in the Shetlands. Cambridge anthropology seminar.

Clifford, J ./ Marcus, G. (eds.) (1986) Writing Culture. Berkeley: California University Press.

Deutscher, I. (1970) Words and Deeds. In: Filstead, W. (ed.) Qualitative Methodology: Firsthand Involvement with the Social World. Chicago: Markham, 27- 51.

Douglas, M. (1966) Purity and Danger. London: Routledge and Kegan Paul.

Emerson, R./ Fretz, R./ Shaw, L. (eds.) (1995) Writing Ethnographic Fieldnotes. University of Chicago Press: Chicago.

Groper, R. (1975) Gypsies in the City. Princetown: Darwin Press.

Guy, W. (1975) Ways of Looking at Rom. In: Rehfisch, F. (ed.) Gypsies, Tinkers and Other Travellers. London: Academic.

Hannerz, U. (1969) Soulside: inquiries into ghetto culture and community. New York: Columbia University Press.

J ackson, B. and Marsden, D. (1962), Education and the working class, London: Routledge and Kegan Paul.

Kaminski, I. M. (1980) The State of Ambiguity: Studies of Gypsy Refugees. Gothenburg: Anthropological Research. 
Leach, E. (1967) An anthropologist's reflections on a sociological survey. In: J ongmans, D./

Gutkind, P. (eds.) Anthropologists in the Field. Assen: Van Gorcum, 75- 88.

Leach, E. (1968) Pul Eliya: A villagein Ceylon: A Study of Land Tenure and Kinship. Cambridge: Cambridge University Press.

Leach, E. (1972) Anthropological Aspects of Language: Animal Categories and Verbal abuse. In: Maranda, P. (ed.) Mythology. London: Penguin.

Levi-Strauss, C. (1973) Tristes Tropiques (transl. J . and D. Weightman). London: Cape.

McDonald, M. or 'Gertrude' (1978) A Postface to a few Prefaces. In: J ournal of the Anthropology Society of Oxford (JASO), Trin. Vol. 1X, 2: 133- 142.

Malinowski, B. (1922) The Argonauts of the Western Pacific. London: Routledge and Kegan Paul.

Malinowski, B. (1967) A Diary in the Strict Sense of the Term. London: Routledge and Kegan Paul.

Marcus, G./ Okely, J . (2007) How short can fieldwork be? Debate Section. In: Social Anthropology, Vol. 15, (3): 353- 367.

M.H.L.G (Ministry of Housing and Local Government) (1967) Gypsies and Other Travellers. London: Her Majesty's Stationery Office.

Okely, J . (1975a) The Self and Scientism. In: J ournal of the Anthropology Society of Oxford. Michaelmas term: 171- 188. Reprinted in Okely (1996), Ch.2.

Okely, J . (1975b) Gypsy women: Models in Conflict. In: Ardener, S. (ed.) Perceiving Women. London: Malaby. Reprinted in Okely (1996), Ch 4.

Okely, J . (1983) The Traveller-Gypsies. Cambridge: Cambridge University Press.

Okely, J . (1987) Fieldwork up the M1: policy and political aspects. In: J ackson, A. (ed.) Anthropology at Home. London: Tavistock, 55- 73.

Okely, J ._(1992) Anthropology and autobiography: participatory experience and embodied knowledge. In: Okely, J ./ Callaway, H. (eds.) Anthropology and Autobiography. London: Routledge, 1- 28.

Okely, J . (1994) Thinking through fieldwork. In: Burgess, R./ Bryman, A. (eds.) Analysing Qualitative Data. London: Routledge, 18-34.

Okely, J . (1996) Own or Other Culture. London: Routledge.

Okely, J . (1997a) Non Territorial culture as the rational for the assimilation of Gypsy children. In: Childhood, Vol. 4 (1): 63-80. 
Okely, J . (1997b) Some political consequences of theories of Gypsy ethnicity: the place of theintellectual. In:J ames, A./ Hockey, J ./ Dawson, A. (eds.) After Writing Culture. London: Routledge, 224- 243.

Okely, J . (2005) Gypsy J ustice and Gorgio Law: Interrelations of Difference. In: The Sociological Review, Vol. 53 (4), 691- 709.

Okely, J . (2008) Knowing without Notes. In: Halstead, N./Hirsch, E./ Okely, J . (eds.) Knowing how to Know: Fieldwork and the Ethnographic Present. Oxford: Berghahn, 55- 74.

Okely, J . (2009) Written Out and Written in Inishkillane Remembered. In: Irish J ournal of Anthropology, Vol. 12 (2): 50- 55.

Okely, J . (2010) Fieldwork as Free Association and Free Passage. In: Melhuus, M./ Mitchell, J ./ Wulff, H. (eds.) Ethnographic Practice in the Present. Oxford: Berghahn, 28- 41.

Okely, J . (2011) (in press) Anthropological Practice: Fieldwork and the Anthropological Method. Oxford: Berg.

Okely, J ./ Callaway, H. (1992) (eds.) Anthropology and Autobiography. London: Routledge, 1- 28.

Powdermaker, H. (1967) Stranger and Friend: The Way of an Anthropologist, London: Secker \& Warburg.

Pratt, M. L. (1986) Fieldwork in Common Places. In: Clifford, J ./ Marcus; G. (eds.) Writing Culture. Berkeley: California University Press, 27- 50.

Sanjek, R. (ed.) (1990) Fieldnotes: The Makings of Anthropology. Ithaca: Cornell University Press. Sarkar, N. K./Tambiah, S. (1957) The Disintegrating Village. Colombo: Ceylon University Press.

Stewart, M. (1997) The Time of the Gypsies. Boulder: Co Westview.

Sutherland, A. (1975) Gypsies: The Hidden Americans. London: Tavistock.

Tambiah, S. (1973) Classification of Animals in Thailand. In: Douglas, M. (ed.) Rules and Meanings. Harmondsworth: Penguin.

Thomas, K. (1971) Religion and the Decline of Magic. London: Weidenfeld and Nicholson.

Thompson, T. W. (1922) The Uncleanness of Women among English Gypsies. In: J ournal of the Gypsy Lore Society, third series, Vol. 1(1-2): 15- 43.

Van Maanen, J . (1988) Tales of the Field: on Writing Ethnography. Chicago: University of Chicago Press.

Whyte, W. F. (1943/ 1966) Street Corner Society: The Social Structure of an Italian Slum. Chicago: University of Chicago Press.

Buletin, L., 2017. Berita Terkini. [Online] Available at: http://www.buletinlokal.com/ 